\title{
Aortic stenosis with abnormal eccentric left ventricular remodeling secondary to hypothyroidism in a Bourdeaux Mastiff
}

\section{Guilherme Augusto Minozzo ${ }^{1}$ Simone Tostes de Oliveira Stedile ${ }^{2}$ Marlos Gonçalves Sousa ${ }^{2 *}$}

\footnotetext{
${ }^{1}$ Programa de Pós-graduação em Ciências Veterinárias, Universidade Federal do Paraná (UFPR), Curitiba, PR, Brasil.

${ }^{2}$ Departamento de Medicina Veterinária, Universidade Federal do Paraná (UFPR), 80035-050, Curitiba, PR, Brasil. E-mail: marlos98@ufpr.br. ${ }^{*}$ Corresponding author.
}

\begin{abstract}
This paper describes a case of congenital aortic stenosis with eccentric left ventricular hypertrophy associated with hypothyroidism in a 1-year-old Bourdeaux Mastiff dog. The dog had ascites, apathy, alopecic and erythematous skin lesions in different parts of the body. A two-dimensional echocardiogram revealed aortic valve stenosis, with poststenotic dilation in the ascending aorta. The same exam showed eccentric hypertrophy and dilation of the left ventricle during systole and diastole. Aortic stenosis usually results in concentric left ventricular hypertrophy instead of eccentric hypertrophy; and therefore, this finding was very unusual. Hypothyroidism, which is uncommon in young dogs, may be incriminated as the cause of ventricular dilation, making this report even more interesting. Because hypothyroidism would only result in dilatation, the eccentric hypertrophy was attributed to pressure overload caused by aortic stenosis. Thus, cardiac alterations of this case represent a paradoxical association of both diseases.

Key words: hypothyroidism, echocardiogram, ascending aorta, left ventricular dilation, heart disease.
\end{abstract}

Estenose aórtica com remodelamento excêntrico anormal do ventrículo esquerdo secundário ao hipotireoidismo em um cão Dogue de Bordeaux

RESUMO: Este trabalho descreve um caso de estenose aórtica congênita com hipertrofia excêntrica do ventrículo esquerdo associado ao hipotireoidismo em um cão Dogue de Bordeaux. O cão, de um ano de idade, apresentava ascite, apatia, lesões cutâneas alopécicas e eritematosas generalizadas. Na ecocardiografia bidimensional foi observada estenose da valva aórtica, com dilatação pós-estenótica em aorta ascendente. Foi detectado, no mesmo exame, hipertrofia excêntrica e dilatação do ventrículo esquerdo em sístole e diástole. Usualmente, como consequência, a estenose aórtica causa hipertrofia concêntrica do ventrículo esquerdo e não hipertrofia excêntrica, sendo este achado infrequente em tal cardiopatia. O hipotireoidismo, incomum em cães jovens, pode representar a causa da dilatação ventricular observada, o que torna mais relevante esse relato. Como no hipotireoidismo é esperado apenas dilatação, a hipertrofia excêntrica supostamente é atribuida à sobrecarga de pressão causada pela estenose aórtica. Dessa forma, as alterações cardíacas deste caso representam uma associação paradoxal das duas afecções.

Palavras-chave: hipotireoidismo, ecocardiografia, aorta ascendente, dilatação do ventrículo esquerdo, cardiopatia.

Aortic stenosis is a congenital heart disease characterized by a partial narrowing of the left ventricular outflow tract (SISSON et al., 2004). In dogs, the disease is called subaortic stenosis (SAS) because the obstruction to flow is usually caused by fibrous tissue located proximal to the valve (Mac DONALD, 2006).

In both aortic stenosis and SAS, the aortic pressure is normal, but the resistance imposed by the luminal narrowing increases the pressure gradient (PG) across the lesion due to the elevated systolic pressure within the left ventricle (LV). The increased tension on the LV wall causes an increase in muscular mass, which translates into concentric left ventricular hypertrophy and may result in impaired LV filling and reduced cardiac output (KIENLE, 2000).

In this paper, we report an unusual case of aortic stenosis in a dog exhibiting eccentric LV remodeling rather than concentric hypertrophy, which later was determined to be due to systolic myocardial failure secondary to hypothyroidism.

A one-year old Bordeaux Mastiff was examined for abdominal distension and 
dermatological abnormalities. Its history included prostration, lethargy, inappetence and a distended abdomen for the past two weeks, as well as alopecia and generalized cutaneous erythema. Cardiopulmonary auscultation showed muffled heart sounds, an irregularly irregular rhythm, and wheezes over the dorso-caudal lung fields. Skin examination disclosed generalized alopecia, with several pustules and papules throughout the body, as well as crusts and a rancid odor. The dog was cachectic and had ascites, which was drained and classified as a transudate on laboratory analysis. Abdominal ultrasonography was undertaken after the abdomen was tapped, and only liver enlargement could be documented.

A normocytic normochromic anemia was observed on the CBC. A complete serum biochemistry profile was performed (creatinine, BUN, alanine aminotransferase, alkaline phosphatase, aspartate aminotransferase, gamaglutamyl transferase, total protein and protein fractions, total cholesterol, sodium, potassium and ionized calcium). Only BUN, total protein, globulin, and potassium were increased, while the albumin concentration was reduced. A urinalysis documented traces of protein, as well as renal pelvis epithelial cells. Microscopic assessment of skin scrapings identified Demodex canis, while bacterial culture of the skin resulted in a profuse growth of Staphylococcus pseudintermedius, which was deemed secondary to the parasitic folliculitis.

The echocardiogram (Figure 1; Table 1) documented left ventricular dilation in both systole and diastole, reduced fractional shortening (14\%) and ejection fraction $(30 \%)$, and an increased E-point septal separation $(14.7 \mathrm{~mm})$, which suggested systolic myocardial failure with eccentric left ventricular remodeling. Also, the left atrium (LA) dimension was increased, as was the LA/aorta ratio (1.83). The Doppler assessment of aortic flow reported an increased peak velocity $\left(4.37 \mathrm{~m} \mathrm{~s}^{-1}\right)$, resulting in an augmented pressure gradient between the left ventricle and the aorta $(76.4 \mathrm{mmHg})$. Aortic cusp morphology was markedly altered, with dysplastic and fused valves that narrowed the aortic lumen. All of these findings were compatible with moderate aortic stenosis (BUSSADORI et al., 2000). Moreover, both a post-stenotic dilatation at the ascending aorta and aortic valve insufficiency were observed. Tricuspid valve insufficiency allowed the systolic pulmonary pressure to be estimated at $33 \mathrm{mmHg}$.

The electrocardiogram (Figure 2) showed an irregularly irregular rhythm reaching up to $220 \mathrm{bpm}$, and no $\mathrm{P}$ waves, which was consistent with atrial fibrillation. Also, the QRS complexes were increased in duration, suggesting left ventricular overload.

Shortly after the diagnosis of aortic stenosis and systolic myocardial failure was established, the patient was put on diltiazem $\left(0.42 \mathrm{mg} \mathrm{kg}^{-1}\right.$ TID PO), digoxin $\left(0.005 \mathrm{mg} \mathrm{kg}^{-1}\right.$ BID PO), enalapril $(0.42 \mathrm{mg}$ $\mathrm{kg}^{-1}$ BID PO) and furosemide (2mg kg-1 TID SQ). Even though diltiazem has known negative inotropic effects, SCHWINGER et al. (1990) demonstrated that benzothiazepine calcium channel blockers are less likely to reduce contractility compared to either phenylalkylamine calcium channel blockers, including verapamil, or dihydropyridine drugs such as nifedipine. Moreover, the use of beta blockers would likely produce a more pronounced impairment in contractility. In this dog, the goal of diltiazem was to control the heart rate; therefore, reducing oxygen consumption by the ventricular myocytes, which would possibly minimize the progression of systolic dysfunction. In this regard, a study that included 18 dogs with atrial fibrillation found that the combination of diltiazem and digoxin was more efficient than either drug alone to control ventricular heart rate, and was effective at maintaining the heart rate below $140 \mathrm{bpm}$ during $85 \%$ of the holter assessment time (GELZER et al., 2009). Finally, doramectin $\left(0.6 \mathrm{mg} \mathrm{kg}^{-1} \mathrm{SQ}\right.$ every 7 days) and cephalexin (20 $\mathrm{mg} \mathrm{kg}^{-1}$ BID PO) were also recommended to treat the cutaneous disease.

The heart rate was carefully monitored over the few days following diagnosis. Although an important reduction to approximately $140 \mathrm{bpm}$ was documented, sinus rhythm did not resume. Nonetheless, the dog was clinically stable, and no other signs attributable to either left or right congestive heart failure could be observed. An additional echocardiogram showed minimal variation in systolic indices as compared to the first evaluation.

The skin lesions improved markedly, with hair growing in areas that were previously alopecic. However, because cutaneous lesions were still visible after 16 weeks, another skin scraping was undertaken. At the same time, the combination of cutaneous signs, sleepiness, cold intolerance, and systolic myocardial failure led to the suspicion of hypothyroidism. Radioimmunoassay measurement of free $\mathrm{T} 4$ indicated

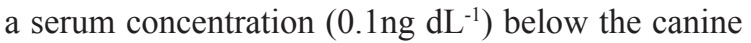
reference range $\left(0.8\right.$ to $\left.3.5 \mathrm{ng} \mathrm{dL}^{-1}\right)$, as well as a TSH level $\left(0.64 \mathrm{ng} \mathrm{mL}^{-1}\right)$ higher than the canine reference range ( 0.04 to $\left.0.4 \mathrm{ng} \mathrm{mL}^{-1}\right)$, which indicated primary hypothyroidism. Therefore, levothyroxine sodium $(11.4 \mu \mathrm{g} / \mathrm{kg}$ BID PO) was prescribed as well.

Ten months after the first evaluation, the patient was still being given the same medications 

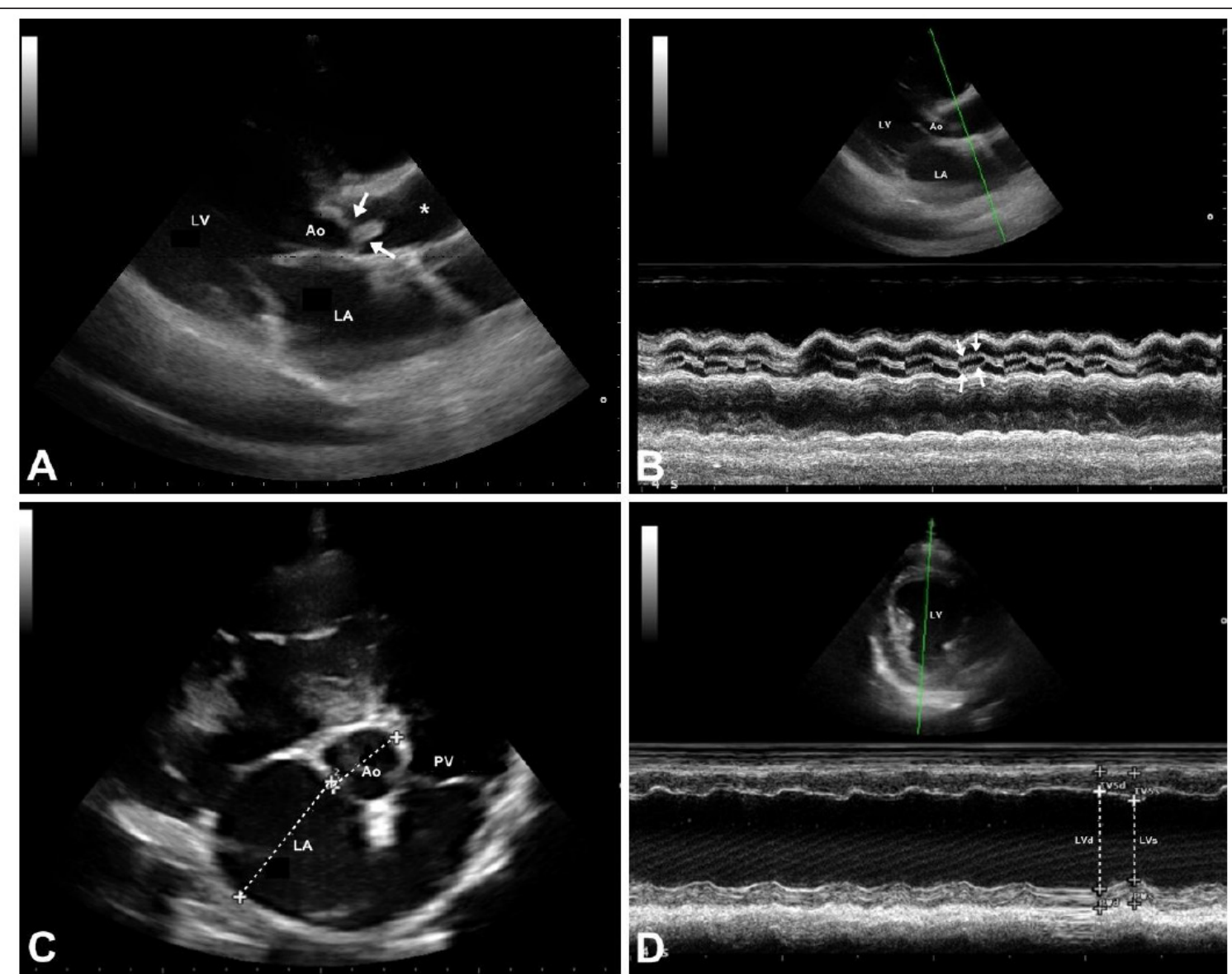

\section{D}
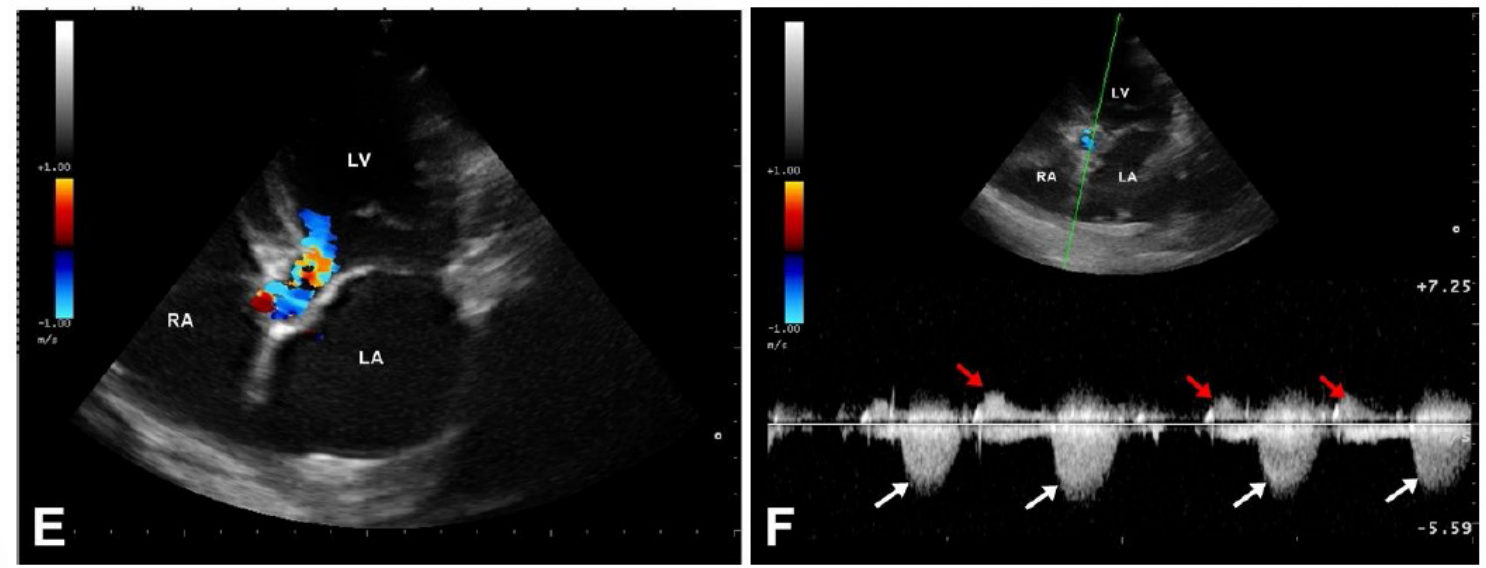

Figure 1 - A. Longitudinal echocardiographic image obtained from the right parasternal window, showing dysplastic and fused aortic valve cusps (arrows), resulting in outflow obstruction and post-stenotic dilation ("); B. M-mode echocardiogram obtained from a longitudinal view of the left-ventricular outflow tract, showing an incomplete opening and fluttering (arrows) of the aortic valve during ventricular systole; $\mathrm{C}$. Transverse echocardiographic image at the aortic level, obtained from the right parasternal window, showing left atrial dilatation (LA/Ao 1.83); D. M-mode echocardiogram obtained from a left-ventricular transverse image at the papillary muscle level, showing augmented left-ventricular diameters at systole and diastole, which resulted in a reduced fractional shortening (14\%); E. Apical five-chamber image, obtained from the left parasternal window, with the color Doppler superimposed showing a turbulent flow at the left ventricular outflow tract; F. Increased velocity of aortic flow (4.37 $\mathrm{m} \mathrm{s}^{-1}$; white arrows) and aortic regurgitation (red arrows) obtained with the continuous Doppler assessment of left ventricular outflow tract. LA: left atrium; LV: left ventricle; RA: right atrium; RV: right ventricle; Ao: aorta; PV: pulmonary valve; LVd: left-ventricular internal diameter at diastole; LVs: left-ventricular internal diameter at systole.

Ciência Rural, v.47, n.9, 2017. 
Table 1 - Results of the first and control echocardiograms, indicating percent change and reference range for similarly-sized dogs.

\begin{tabular}{lcccc}
\hline & $1^{\text {st }}$ Echo & 2 $\frac{\text { nd }}{2}$ Echo & \% change & Reference Range (35 kg dogs) \\
\hline IVSd & 12.8 & 11.8 & -7.8 & $7-12 \mathrm{~mm}$ \\
LVd & 66.4 & 64.7 & -2.6 & $36-53 \mathrm{~mm}$ \\
\hline LVFWd & 12.7 & 12.8 & +0.8 & $7-12 \mathrm{~mm}$ \\
IVSs & 11.7 & 15.7 & +34.2 & $10-19 \mathrm{~mm}$ \\
LVs & 56.9 & 52.5 & -7.7 & $22-39 \mathrm{~mm}$ \\
LVFWs & 15.1 & 15.9 & +5.3 & $11-19 \mathrm{~mm}$ \\
FS $\%$ & $14 \%$ & $19 \%$ & +35.7 & $25.3-49.9 \%$ \\
EF\% & $30 \%$ & $38 \%$ & +26.7 & $58.9-82.9 \%$ \\
EPSS & $14.7 \mathrm{~mm}$ & $6.5 \mathrm{~mm}$ & -55.8 & $\leq 0.5 \mathrm{~mm}$ \\
LA/Ao & 1.83 & 1.93 & +5.5 & $\leq 1.59 \mathrm{~mm}$ \\
Aortic Flow Velocity & $4.37 \mathrm{~m} / \mathrm{s}$ & $3.92 \mathrm{~m} / \mathrm{s}$ & -10.3 & $0.5-1.5 \mathrm{~m} / \mathrm{s}$ \\
PG (LV-Ao) & $76.4 \mathrm{mmHg}$ & $61.5 \mathrm{mmHg}$ & -19.5 & $1-9 \mathrm{mmHg}$ \\
\hline
\end{tabular}

IVSd: interventricular septum in diastole; LVd: left ventricular internal diameter in diastole; LVFWd: left ventricular free wall in diastole; IVSs: interventricular septum in systole; LVs: left ventricular internal diameter in systole; LVFWd: left ventricular free wall in systole; FS\%: fractional shortening; EF\%: ejection fraction; EPSS: E-point septal separation; LA/Ao: left atrium-to-aorta ratio; PG (LV-Ao): systolic pressure gradient between left ventricle and aorta.

to treat the cardiac failure, arrhythmia and hypothyroidism. The dog was more active and gained weight, and recurrence of ascites was not observed. Atrial fibrillation persisted, but the heart rate was controlled within the normal reference range. Also, the eccentric left ventricular remodeling was still present, but a slight improvement of some systolic indices, including ejection fraction (38\%) and fractional shortening (19\%), was documented (Table 1). Regarding the skin, almost all lesions disappeared, and the animal's hair coat improved in quality.

While this case may not be diagnosed as dilated cardiomyopathy because such disease has to be primary in origin, the young age of the animal and the identification of a secondary cause for cardiac dilation were important to ruled out dilated cardiomyopathy (KEENE, 1994). This unusual alteration might be ascribed to the hypothyroidism, which is recognized as a potential cause of systolic myocardial failure and cardiac dilation. Although, this patient exhibited eccentric left ventricular hypertrophy, such alteration is recognized as an uncommon finding in subjects diagnosed with aortic stenosis, which usually causes concentric hypertrophy secondary to the increased resistance imposed by the ventricular outflow tract obstruction. Thus, the combination of cardiac dilation caused by the impaired contractility and the myocardial hypertrophy attributable to aortic stenosis resulted in eccentric hypertrophy instead of the anticipated concentric hypertrophy on the echocardiogram.
Hypothyroidism is known to cause direct negative inotropic effects owing to a shift from the predominant myosin isoenzyme to the low-ATPase $\beta$-myosin heavy chain in some species; although, this is likely of limited importance in dogs. Also, diastolic relaxation is prolonged and heart rate is reduced by the decreased SERCA (sarco/endoplasmic reticulum calcium ATPase) activity and numbers of $\beta 1$-adrenergic receptors, respectively (KAHALY \& DILLMANN, 2005). In our case, the failing pumping function was apparently responsible for the reduction in cardiac output and the activation of compensatory mechanisms (STRICKLAND, 2006), leading to congestive heart failure and increased preload, and eventually causing the ventricle to remodel eccentrically. Interestingly, hypothyroidism is more common in middle age, medium-to-large breed dogs, which makes this a surprising diagnosis in such a young animal. Indeed, the result of T4 below and TSH above the normal reference ranges was enough to confirm the diagnosis of primary hypothyroidism, which was responsible for the bilateral symmetrical alopecia, lethargy and cold intolerance presented by the animal. The cardiac remodeling with systolic failure and eccentric hypertrophy documented in this patient suggested that the endocrine disease was chronic (DIXON et al., 1999), and in addition to reduced contractility, adult hypothyroid dogs quite commonly present with bradycardia and other cardiac arrhythmias (NELSON \& COUTO, 2014). In this dog, atrial fibrillation was likely attributable to the reduced 


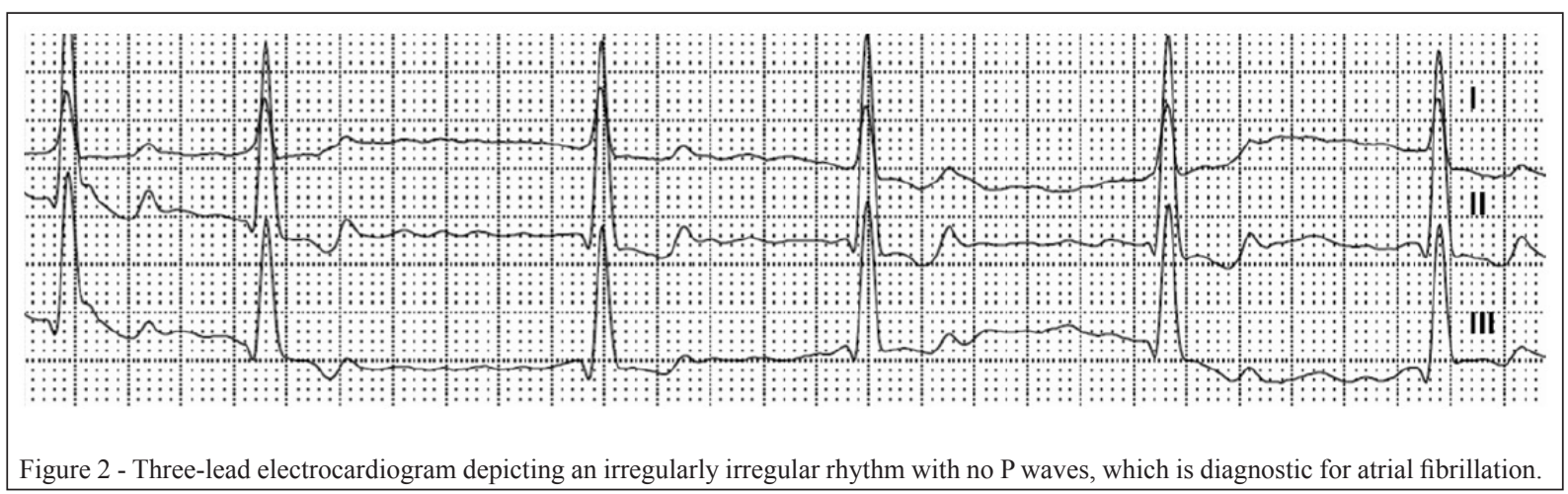

stroke volume and increased left atrial size caused by hypothyroidism. Phillips \& Harkin (2003) diagnosed hypothyroidism and cardiac failure in two dogs, whose echocardiographic findings were similar to those documented in subjects diagnosed with dilated cardiomyopathy, including diminished fractional shortening and augmented left ventricular internal diameters in systole and diastole. Nevertheless, because no overt cause-and-effect relationship could be established, they also speculated that both diseases could be distinct and just coexist. Flood and Rover (2009) reported the case of a dog with hypothyroidism that developed myocardial failure and, accordingly, ascites, myxedema and pleural effusion.

Finally, another relevant aspect of this report was the stenotic lesion which was ascribed to a dysplastic aortic valve instead of a fibrous subaortic ring, the latter of which is the most common obstructive aortic lesion in dogs (COELHO, 2010). It is not common to document eccentric hypertrophy in cases of aortic stenosis, and the combination of a ventricular outflow tract obstruction and secondary myocardial failure is truly scarce. Hypothyroidism was likely responsible for the development of systolic myocardial failure, and was paramount in exacerbating the cutaneous parasitic disease.

In conclusion, even though the combination of a congenital heart disease and acquired systolic myocardial failure leading to congestive heart failure is uncommon in veterinary practice, the treatment was effective in controlling clinical signs and the dog was still alive 24 months after the diagnosis was first established. This report draws the attention to a rare presentation of aortic stenosis due to the effects of hypothyroidism on cardiac function and morphology, which reinforces the importance of fully investigating other potential comorbidities when an unusual clinical scenario is documented.

\section{REFERENCES}

BUSSADORI, C. et al. Guidelines for the echocardiographic studies of suspected subaortic and pulmonic stenosis. Journal of Veterinary Cardiology, v.2, p.15-22, 2000. Available from: $<$ http://www.sciencedirect.com/science/article/pii/ S1760273406700078?via\%3Dihub>. Accessed: Nov. 28. 2015. doi: 10.1016/S1760-2734(06)70007-8.

COELHO, A.C.G. Estudo Retrospectivo da Estenose Aórtica no Cão. Dissertação (Mestrado Integrado em Medicina Veterinária) - Ciências Veterinárias, Universidade de Trás-Os-Montes e Alto Douro, Vila Real, Portugal.

DIXON, R.M. et al. Epidemiological, clinical, haematological and biochemical characteristics of canine hypothyroidism. Veterinary Record, n.145, p. 481-487, 1999. Available from: <http://www. ncbi.nlm.nih.gov/pubmed/10596870> Accessed: Nov. 02. 2015. doi: 10596870 .

FLOOD, J.A.; HOOVER, J.P. Improvement in myocardial dysfunction in a hypothyroid dog. Canadian Veterinary Journal, v.50, p.828-834, 2009. Available from: <http://www.ncbi.nlm.nih.gov/pmc/articles/ PMC2711467/>. Accessed: Dec. 01. 2015. doi: PMC2711467/.

GELZER, A.R.; et al. Combination therapy with digoxin and diltiazem controls ventricular rate in chronic atrial fibrillation in dogs better than digoxin or diltiazem monotherapy: a randomized crossover study in 18 dogs. Journal Veterinary Internal Medicine, v.23, p.499-508, 2009. Available from: <http://www.ncbi.nlm.nih. gov/pubmed/19645836>. Accessed: Nov. 15.2015. doi: 10.1111.

KAHALY, G.J.; DILLMANN, W.H. Thyroid hormone action in the heart. ENDOCRINE REVIEWS. v.26, p.704-728, 2005. Available from: <https://academic.oup.com/edrv/article-lookup/ doi/10.1210/er.2003-0033.> Accessed: Dec. 05. 2015. doi: 10.1210/er.2003-0033.

KEENE, B.W. Dilated cardiomyopathy in dogs: diagnosis and long-term management. In: ANNUAL WALTHAM SIMPOSIUM FOR THE TREATMENT OF SMALL ANIMAL DISEASESCARDIOLOGY. The annual cardiology. Ohio: Waltham, 1994. v.18, p. 27-32.

KIENLE, R. Estenosis aórtica. In: KITTLESON, M.; KIENLE R. Medicina cardiovascular de pequeños animales. Espanha: Multimédica, 2000. Cap.16, p.260-271. 
MAC DONALD, K.A. Congenital heart diseases of puppies and kittens. Veterinary Clinics of North America: Small Animal Practice, v.36, p.503-531, 2006. Available from: $<$ http://www.sciencedirect.com/science/article/pii/ S0195561605001920?via\%3Dihub>. Accessed: Nov. 01. 2015. doi: $10.1016 /$ j.cvsm.2005.12.006

NELSON, R.W.; COUTO, C. G. Cardiopatia Congênita. In: NELSON, R.W.; COUTO, C. G. Medicina Interna de Pequenos Animais. Elsevier Editora Ltda, 2010. p. 95-112.

PHILLIPS, D.E.; HARKIN, K.R. Hypothyroidism and Myocardial Failure in Two Great Danes. Journal American Animal Hospital Association, v.39, p.133-137, 2003. Available from: $<$ http://www. ncbi.nlm.nih.gov/pubmed/12617541>. Accessed: Nov. 01. 2015. doi: 12617541 .
SCHWINGER, R.H.G.; et al. Negative inotropic properties of isradipine, nifedipine, diltiazem and verapamil in diseased human myocardial tissue. Journal of Cardiovascular Pharmacology, v.15, p. 892-899, 1990. Available from: <http:// www.ncbi.nlm.nih.gov/pubmed/1694911>. Accessed: Dec. 01. 2015. PMID: 1694911.

SISSON, D.D. et al. Cardiopatia congênita. In: ETTINGER, S.J.; FELDMAN, E. C. Tratado de medicina interna veterinária: doenças do cão e do gato. Rio de Janeiro: Guanabara Koogan, 2004. p.780-817.

STRICKLAND, K.N. Pathophysiology and Therapy of Heart Failure. In: SMITH, JR., F. W. et al. Manual of Canine and Feline Cardiology. St. Louis: Elsevier, 2016. p. 287-312. 